\title{
Nodulation in Onobrychis Perennial Legume Plants
}

\author{
Zair S. Shakirov ${ }^{1 *}$, Sardor A. Khakimov ${ }^{1}$, Khabibullo F. Shomurodov ${ }^{2}$, Bakhtiyar R. Umarov ${ }^{1}$ \\ ${ }^{1}$ Institute of Microbiology of Uzbekistan Academy of Sciences, Tashkent, Republic of Uzbekistan; ${ }^{2}$ Scientific Center of Plant \\ Production "Botanika", Uzbekistan Academy of Sciences, Tashkent, Uzbekistan. \\ Email: ${ }^{*}$ zair@dostlink.net
}

Received July $12^{\text {th }}, 2010$; revised August 27 $7^{\text {th }}, 2010$; accepted September $9^{\text {th }}, 2010$.

\begin{abstract}
A total of 110 strains of nodule bacteria was isolated from plants Onobrychis transcaucasica and Onobrychis chorassanica. Nodulation study of bacteria in both Onobrychis plant species in microvegetation experiment gave a very low nodulation on plant roots. The intensive nodulation of Onobrychis plants was recorded in vegetation experiment and for Onobrychis transcaucasica the efficiently-nodulating strains were found OT102, OT103, OT117, OT121, OT130, OT136, OT139, OT140, while for Onobrychis chorassanica plants - OC106, OC107, OC109, OC112, OT103, OT117 and OT123 strains. Nucleotide sequencing of the 16S rRNA gene and BLAST analysis showed that nodule bacteria of Onobrychis plants were related to Rhizobium, Burkholderia, Enterobacter and Pantoea genera. It has been shown a possibility of growing up of Onobrychis plants at minimal additional moisture of sabulous soils in the Kyzyl Kum Desert, creating artificial pastures and thereby immobilizing the desert blown sands.
\end{abstract}

Keywords: Onobrychis Transcaucasica, Onobrychis Chorassanica, Nodulation, Nitrogen Fixation, 16S rRNA, Rhizobium, Burkholderia, Enterobacter, Pantoea

\section{Introduction}

Although more than on 32 millions Ha world wide alfalfa is grown, it is conducted a search for new special purpose forage legumes supported by smaller plantings of species of Coronilla, Onobrychis, and Lotus [1].

Actually, there was tried an Onobrychis inoculation experiment, but due to too low germination rates of seeds and poorer nodulation, no reliable data were obtained [2]. Rhizobia from Canadian soils were selected for cold adaptation with the aim of improving productivity of legumes that are subjected to cool temperatures during the growing season [3]. One approach was to use rhizobia associated with legume species indigenous to arctic and subarctic regions: Mesorhizobium sp. isolated from Astragalus, Oxytropis spp. and Rhizobium leguminosarum from Lathryrus spp. The majority of these rhizobia are considered as psychrotolerant because they can grow at $0^{\circ} \mathrm{C}$. The advantages of cold adaptation of arctic Mesorhizobium to improve legume symbiosis were demonstrated with the temperate forage legume sainfoin (Onobrychis viciifolia). In laboratory and field studies, arctic rhizobia were more efficient than temperate (commercial) rhizobia in improving growth of sainfoin and were more competitive in forming nodules. Biochemical studies on cold adaptation showed higher synthesis of cold shock proteins in cold-adapted than in non-adapted arctic rhizobia. Since arctic Mesorhizobium cannot nodulate agronomically important legumes, the nodulation genes and the bacterial signals (Nod factors) were characterized as a first step to modifying the host specificity of nodulation [3].

The genetic diversity of 44 rhizobial isolates from $A s-$ tragalus, Oxytropis, and Onobrychis spp. originating from different geographic locations was evaluated by mapped restriction site polymorphism (MRSP) analysis of $16 \mathrm{~S}$ rRNA genes and by PCR DNA fingerprinting with repetitive sequences (REP-PCR) [4]. From the REPPCR data, authors identified only three examples in which rhizobia from a single plant species appeared to be closely related (the two strains from Astragalus sinicus, two strains from Onobrychis viciifolia, and three strains from Astragalus cicer). These results agree with previous classifications of other publications by serology, by numerical taxonomy, and by cross-infection experiments in which rhizobia from Astragalus, Oxytropis, and Onobrychis spp. were grouped independently of their plant 
origin [4].

Five isolates from sainfoin (Onobrychis viciifolia, tribe Hedysareae, related to the tribe of Galegeae) were included because this legume species was effectively nodulated by rhizobia isolated from Astragalus and Oxytropis [5]. The nitrogenase activities of five arctic rhizobia isolates were higher at low temperatures than those of temperate rhizobia when symbiotic with the legume sainfoin (Onobrychis viciifolia Scop.) [6]. It was also found that a strain isolated from a cold environment caused nodulation and formed bacteroids under low temperatures while a strain isolated from a warmer environment did not [7].

Since Phaseolus vulgaris is a promiscuous host nodulated by at least six species of rhizobia, introduced plants could also have established symbiosis with rhizobia from Leucaena, Onobrychis, Dalea, etc. [8], with other words, nodule bacteria isolated from Onobrychis plants could display cross-inoculation host specificity towards to the strange host-plant.

The tasks of the present research included a study of symbiotic properties of 110 nodule bacteria isolated from nodules of Onobrychis transcaucasica and Onobrychis chorasanica, as well as their generic and specific (species) belonging, and also the sand immobilization with help of Onobrychis symbiosis aiming to create artificial semi-desert pastures and increase their productivity.

\section{Materials and Methods}

\subsection{Isolation and Purification of Nodule Bacteria from Onobrychis Plants}

Nodules with pink and fallow tissue were taken from the root system of both Onobrychis species. The nodules were surface-sterilized with $30 \% \mathrm{H}_{2} \mathrm{O}_{2}$ for $30 \mathrm{~s}$ and washed several times with sterile distilled water [9]. Sterile nodules were crushed gently up to homogenous state and the nodule contents were streaked on medium of the following composition $(\mathrm{g} / \mathrm{L})$ : glucose -5 , sucrose $-5, \mathrm{~K}_{2} \mathrm{HPO}_{4}-0.5, \mathrm{KH}_{2} \mathrm{PO}_{4}-0.5, \mathrm{MgSO}_{4} \cdot 7 \mathrm{H}_{2} \mathrm{O}-0.5$, $\mathrm{CaSO}_{4}-0.2$, pea -50 , agar-20, water distilled - up to 1 L, pH 6.8-7.0 (pea was boiled during 1 hour and the medium was prepared on the basis of pea's broth) [10]. The bacteriological-pure nodule bacteria were isolated from single grown colonies.

\subsection{Microvegetation and Vegetation Experiments}

For microvegetation experiments Onobrychis seeds were treated by concentrated sulphuric acid during 4 minutes, then after their numerous washing by sterile water the treated seeds were put on sterile wet discs from filter paper into Petri dishes and were incubated in thermostat at $30^{\circ} \mathrm{C}$ temperature for $1-2$ days before their germination. The germinated seeds further were introduced into tubes with volume $60 \mathrm{ml}$ with sterile mixture sand: vermiculite (3:1), height of which was $8 \mathrm{~cm}$, containing nutritive medium for plants, into each tube there was added $8 \mathrm{ml}$ of this medium: $\mathrm{MgSO}_{4} \cdot 4 \mathrm{H}_{2} \mathrm{O}-5 \mathrm{mM}, \mathrm{K}_{2} \mathrm{SO}_{4}-10 \mathrm{mM}$, $\mathrm{CaCl}_{2} \cdot 2 \mathrm{H}_{2} \mathrm{O}-1 \mathrm{mM}$, phosphate buffer $\left(\mathrm{NaH}_{2} \mathrm{PO}_{4}+\right.$ $\left.\mathrm{Na}_{2} \mathrm{HPO}_{4}, \mathrm{pH} 6.5\right)-15 \mathrm{mM}$, Fe-Sequestrene $138(\mathrm{Fe}-$ EDDHA) $-5 \mathrm{mM}$, microelements $-0.05 \mathrm{ml} / \mathrm{L}$ of medium. Microelements $(\mathrm{g} / \mathrm{L}): \mathrm{H}_{3} \mathrm{BO}_{3}-17.16, \quad \mathrm{MnSO}_{4}-7.2$, $\mathrm{ZnSO}_{4}-1.32, \mathrm{CuSO}_{4}-1.65, \mathrm{Na}_{2} \mathrm{MoO}_{4}-0.12$ [11].

In vegetation experiment the plants were grown within bags of $2 \mathrm{~L}$ volume that were filled by sand impregnated with nutritive medium. After appearance of seedlings of germinated seeds, they were inoculated with bacterial suspensions of 3-daily nodule bacteria cultures that were prepared in the nutritive medium solution in titre $10^{9}$ cells $/ \mathrm{ml}$ (on $2 \mathrm{ml}$ of microelements solution per each tube together with $10 \mathrm{ml}$ of bacterial suspension in the nutriative medium per each bag). In microvegetation experiment the plant seedlings were inoculated by all isolates that were isolated from nodules of both Onobrychis plant species. In vegetation experiment the plant seedlings were inoculated by Onobrychis transcaucasica isolates (OT102, OT103, OT111, OT114, OT115, OT117, OT118, OT121, OT122, OT123, OT124, OT130, OT136, OT139, OT140, OT148, OT151) and Onobrychis chorassanica isolates (OC104, OC106, OC107, OC109, OC111, OC112, OC113, OC138). The inoculated Onobrychis seedlings were cultivated in sterile conditions during 45 days. Each variant of inoculation was done in 3 repeats on 2 plants per each repeat (in vegetation experiment - 5 plants/repeat).

\subsection{Determination of Nitrogen-Fixing Activity}

Nitrogen-fixing activity was estimated by the acetylenereductase activity (ARA) assay described by Hardy [12]. The plant samples (with root nodules) were washed with sterile water and transferred into $60 \mathrm{ml}$ capacity agronomic tubes fitted with airtight rubber stoppers. Acetylene (10 volume \%) was injected and the tubes were incubated at $30^{\circ} \mathrm{C}$ for 24 hours. The data was the mean of three replicates. The samples without acetylene were used as control. The quantitative estimation of ethylene gas produced in the samples was measured on a gas chromatograph (LHM-80). The acetylene-reductase activity of the plants was expressed as nmoles $\mathrm{C}_{2} \mathrm{H}_{4}$ / tube/hour.

\subsection{PCR Amplification of the 16S rRNA Gene}

The 16S rRNA gene from nodule bacteria of Onobrychis transcaucasica and Onobrychis chorassanica was amplified using universal primers 1070f (59-ACGGGCGGTG 
TGTAC-39) and 1392r (59-CGCCCGCCGCGCCCCGC GCCCGGCCCGCCGCCCCCGCCCCACGGGCGGTG TGTAC-39) [13]. Each PCR mixture contained the following: 10 pmol each primer, $200 \mu \mathrm{M}$ dNTPs, $1 \mathrm{U}$ Tag DNA polymerase, $100-200 \mathrm{ng}$ genomic DNA and Taq polymerase buffer in a final reaction volume of $50 \mu \mathrm{l}$. The DNA thermal cycler used for PCR amplification was programmed as follows: an initial extensive denaturation step at $94^{\circ} \mathrm{C}$ for $5 \mathrm{~min} ; 30$ cycles of $94^{\circ} \mathrm{C}$ for $1 \mathrm{~min}, 53^{\circ} \mathrm{C}$ for $1 \mathrm{~min}$ and $72^{\circ} \mathrm{C}$ for $1.5 \mathrm{~min}$; and a final extension step at $72^{\circ} \mathrm{C}$ for $10 \mathrm{~min}$.

\subsection{Phylogenetic Analysis}

The complete 300-354-bp 16S rRNA gene sequences were compared with the sequences available in the GenBank database using the standard Basic Local Alignment Search Tool, BLASTn [14], at the National Center for Biotechnology Information (NCBI) (http://blast.ncbi.nlm. nih.gov/Blast.cgi). From the aligned sequences, neighborjoining dendrograms [15] were constructed with the software MEGA version 4.0.2 [16]. The robustness of the inferred trees was evaluated by 1000 bootstrap resamplings.

\subsection{Field Experiments on Sand Immobilization}

The plot for field experiments on sand immobilization was chosen in area that was represented by clay (sabulous) sand and all area surrounded experimental plot served as control plot without sowing. A square plot with the area of $400 \mathrm{~m}^{2}$ was divided into four square subplots of $100 \mathrm{~m}^{2}$, which in turn were divided into allotments of $10 \mathrm{~m}$ length and $0.7 \mathrm{~m}$ width. Seeds ( 3 seeds/hole) were sown at $0.25 \mathrm{~m}$ intervals along the length the edge of each allotment. Seeds of Onobrychis transcaucasica and Onobrychis chorassanica were inoculated with $10^{9}$ cells $/ \mathrm{ml}$ suspensions of 3-daily grown cultures of bacterial strains as described before [10]. Control plots were sown with non-inoculated seeds.

\section{Results}

\subsection{Isolation of Nodule Bacteria}

Onobrychis is related to Fabaceae family, Hedysarea tribe, Onobrychis genus. Onobrychis chorassanica is a drought- (xerophyte) and frost-resistant leguminous plant with multiply (up to 20) straight sprouts with height 0.9-1.2 m [17]. Onobrychis chorassanica is a steppe plant, which grows in sandy, rubbly, dried zones, on rocky slopes of mountains and foothills and speckled ores of Tien Shan, Pamirs-Alai, Kopetdag, Iranian plateau and in the Northern Afganistan (Figure 1(a)). Onobrychis transcaucasica is widespread among mountain meadow and steppe areas of Azerbaijan, Georgia and Armenia [18], it

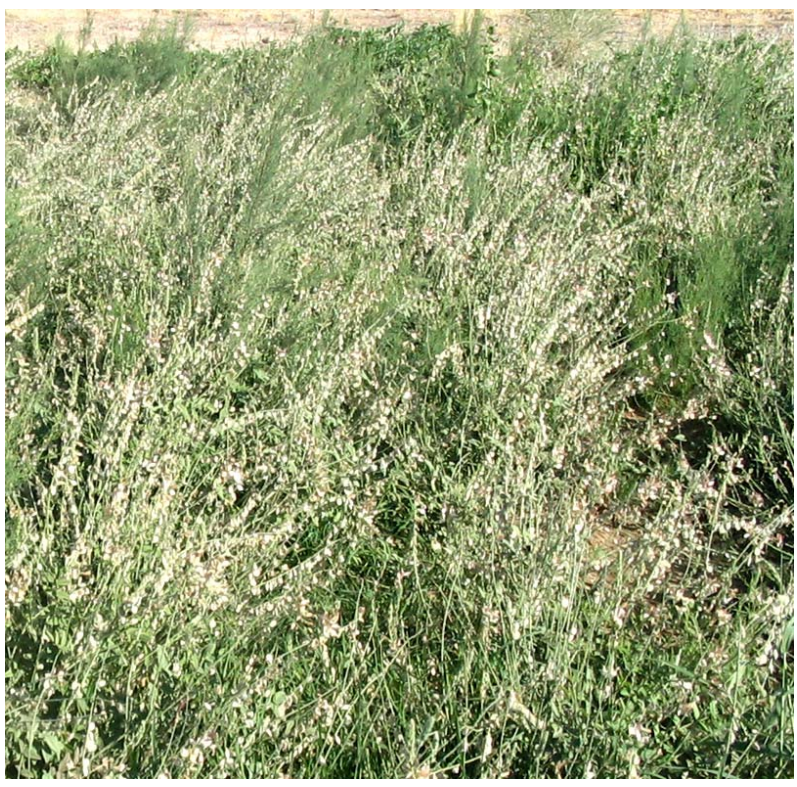

(a)

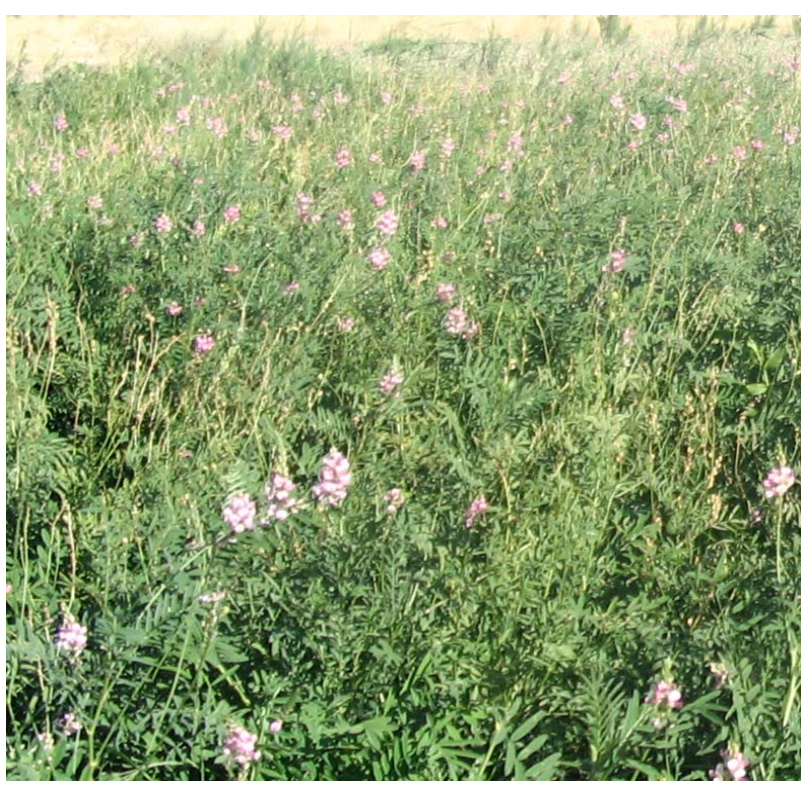

(b)

Figure 1. The appearance of Onobrychis chorassanica (a) and Onobrychis transcaucasica (b) plants.

is mezoxerophyte, which was introduced earlier into Uzbekistan (Figure 1(b)). For isolation of natural nodule bacteria the nodules were gathered from the roots of Onobrychis transcaucasica and Onobrychis chorassanica plants, growing up in their natural habitats. There have been isolated 65 nodule bacteria from Onobrychis transcaucasica plant nodules and 45 nodule bacteria from Onobrychis chorassanica nodules and it has been created a collection of their nodule bacterial isolates. Microscopic investigations of some bacterial cells of 
selected strains showed that studied cells were represented with typical motile rods, their width varied from 0.5 to 0.8 micron and length - from 1.0 to 1.5 micron. It was marked a polymorphism of cells in dependence on the cell's age - in logarithmic phase of growth the cells were represented with motile cells, whereas in stationary phase of growth the cells lost their motility. The speed of growth of nodule bacteria isolated strains depends on conditions of cultivation and it is one of the most important taxonomic signs. During this well-formed colony of fast-growing bacteria can be obtained by 3-4 days of growth, but for slowly-growing - by 7-10 days. In media containing agar-agar the isolates of nodule bacteria formed colorless, transparent, slimy colonies. Such type of isolates colonies was relevant to S-forms of bacteria.

\subsection{Nodulation Test}

The next stage of investigation there was a research of plant nodulation aiming to select high-efficient bacteria in microvegetation experiments. As it was shown in Fig- ure 2, the inoculated plants in sterile conditions during microvegetation experiment grew and developed well. Examination of nodulation for Onobrychis transcaucasica and Onobrychis chorassanica plants on the 45th day of plant growing up showed that nodulation under inoculation with Onobrychis transcaucasica isolates (65 isolates) occurred only in $4 \%$ from total number of inoculated plants and 13\% in Onobrychis chorassanica (45 isolates). Onobrychis transcaucasica OT102, OT103, OT124, OT148 nodule bacteria formed from 1 to 3 nodules per plant with its original host plant (Onobrychis transcaucasica, direct inoculation). At the same time up to 4 nodules were formed on Onobrychis chorassanica plant roots during inoculation with both their OC106, OC107, OC109 bacteria (direct inoculation) and Onobrychis transcaucasica OT104 bacteria (cross inoculation) (Figure 2). From obtained results it may conclude that so low nodulation in both Onobrychis species undoubtedly depended on growing conditions, although in sterile micro-vegetation experiments the plants grew well,

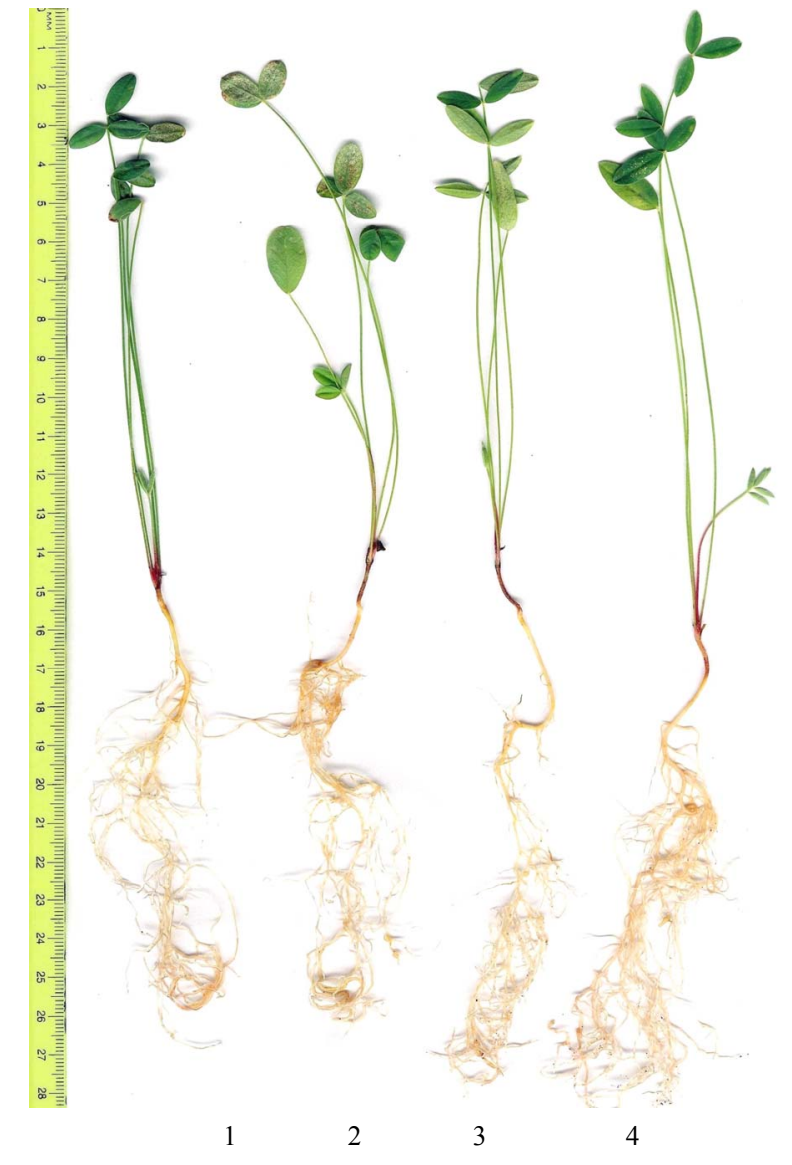

(a)

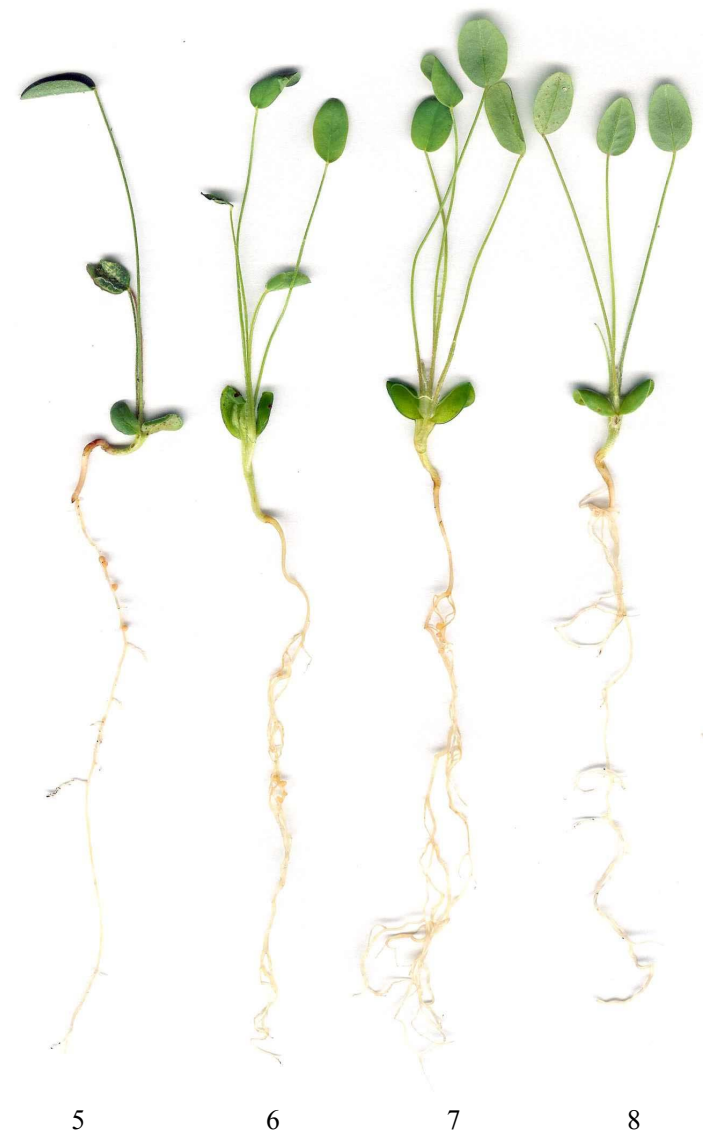

(b)

Figure 2. Nodulation of Onobrychis transcaucasica (a) and Onobrychis chorassanica (b) under inoculation with nodule bacteria in conditions of sterile microvegetation experiment (45- daily plants): 1 -O T102; 2 - OT148; 3 - OT124; 4 - OT103; 5 -OC104; 6-OC106; 7- OC109; 8- OC107. 
but it was not enough for nodule formation on plant roots. According to literature data in nature the nodulation in Onobrychis chorassanica starts by 20-25th day after appearance of sprouts, one week later than in wild species of alfalfa [17]. For getting the high nodulation frequency of Onobrychis plants it was necessary to create more optimal growing conditions than it was in microvegetation experiment. In this connection for finding of the most optimal conditions for nodulation the plants of Onobrychis transcaucasica (grown in microvegetation experiment during 45 days) inoculated with OT139 nodule bacteria and Onobrychis chorassanica plants (grown in microvegetation experiment during 45 days) inoculated by OC140 nodule bacteria were transferred into $2 \mathrm{~L}$ bags with sterile sand as potting material. The further growing up of 45-daily plants in vegetation experiment for one month showed that on roots of Onobrychis plants formed numerous nodules with size $0.3-0.8 \mathrm{~cm}$ and during this the plants developed much better than in microvegetation experiment. In this connection the further experiments on study of nodulation of Onobrychis plants were carried out in sterile vegetation experiment. As results showed, the nodulation in both plant species was observed with different nodule number (Table 1, 2; Figure 3). The intense nodulation was detected more in Onobrychis transcaucasica than in Onobrychis chorassanica plants. Among all of tested strains for Onobrychis transcaucasica plants OT102, OT103, OT117, OT121, OT130, OT136, OT139 and OT140 strains were efficient (Table 1) and for Onobrychis chorassanica plants OC106, OC107, OC109, OC112, OT103, OT117, OT123 strains (Table 2). It should be noted that the biggest efficiency for Onobrychis chorassanica plants was found under cross inoculation with OT123 strain. The acethylene-reductase activity for Onobrychis transcaucasica plants varied within range from 28 to 63 nmoles $\mathrm{C}_{2} \mathrm{H}_{4}$ / hour/tube, while for Onobrychis chorassanica - 29-51 nmoles $\mathrm{C}_{2} \mathrm{H}_{4} /$ hour/tube. The correlation between nitrogen fixation and efficiency was observed in symbiosis of Onobrychis transcaucasica plants with OT117 and OT139 nodule bacteria, but in Onobrychis chorassanica - with OC109 and OT123 The nodule bacteria isolated from nodules of Onobrychis plants displayed cross nodulation specificity (the nodulation specificity towards to non-maternal host plant under cross inoculation of nonmaternal plant) towards to both plant species.

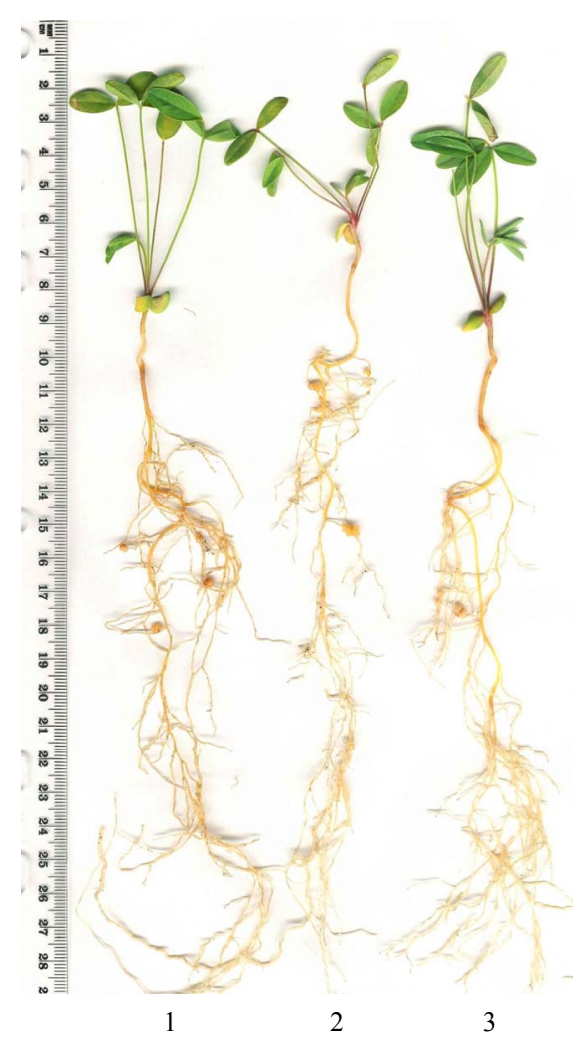

(a)

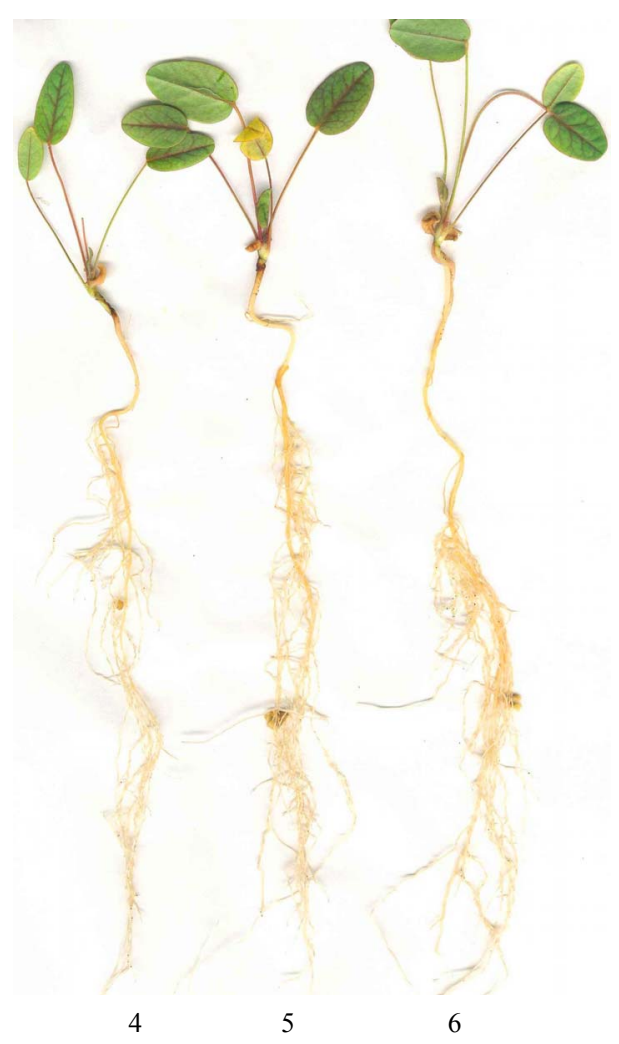

(b)

Figure 3. Nodulation of 1-monthly Onobrychis transcaucasica (a) and Onobrychis chorassanica (b) plants under inoculation with nodule bacteria in conditions of sterile vegetation experiments: 1 - OT117; 2 - OT121; 3 - OT123; 4 - OC104; 5 OC113; 6- OC107. 
Table 1. Nodulation of Onobrychis transcaucasica plants under inoculation with nodule bacteria strains isolated from Onobrychis plants.

\begin{tabular}{|c|c|c|c|c|}
\hline Inoculation variant & $\begin{array}{l}\text { Average dry biomass of } \\
1 \text { plant, mg }\end{array}$ & $\begin{array}{l}\text { Average nodule } \\
\text { number per } 1 \text { plant }\end{array}$ & $\begin{array}{l}\text { ARA, nmoles } \\
\mathrm{C}_{2} \mathrm{H}_{4} / \text { tube/hour }\end{array}$ & $\begin{array}{l}\text { Efficiency } \\
\text { symbiosis, \% }\end{array}$ \\
\hline Control & $81.5 \pm 2.14$ & - & - & 100 \\
\hline OT102 $2^{(1)}$ & $104.0 \pm 3.98$ & $2.0 \pm 1.0$ & $46.0 \pm 11.0$ & 127.6 \\
\hline OT103 & $103.0 \pm 1.99$ & $2.3 \pm 1.5$ & $48.0 \pm 4.58$ & 126.3 \\
\hline OT111 & $98.8 \pm 2.27$ & $1.6 \pm 1.15$ & $51.0 \pm 10,58$ & 121.2 \\
\hline OT114 & $89.8 \pm 5.57$ & $2.6 \pm 0.52$ & $49.0 \pm 8.18$ & 110.1 \\
\hline OT115 & $74.8 \pm 2.41$ & $2.3 \pm 0.57$ & $35.0 \pm 4.58$ & 91.7 \\
\hline OT117 & $111.0 \pm 3.97$ & $2.6 \pm 1.96$ & $59.0 \pm 3.0$ & 136.1 \\
\hline OT118 & $88.0 \pm 1.52$ & $1.3 \pm 0.57$ & $48.0 \pm 7.0$ & 107.9 \\
\hline OT121 & $101.0 \pm 8.08$ & $10.0 \pm 2.64$ & $63.0 \pm 8.88$ & 123.9 \\
\hline OT122 & $87.0 \pm 6.38$ & $4.6 \pm 1.44$ & $58.0 \pm 11.53$ & 106.7 \\
\hline OT123 & $93.6 \pm 6.86$ & $2.3 \pm 0.57$ & $51.0 \pm .56$ & 114.8 \\
\hline OT124 & $97.5 \pm 6.26$ & $2.6 \pm 0.69$ & $53.0 \pm 6.0$ & 119.6 \\
\hline OT130 & $107.0 \pm 4.17$ & $2.3 \pm 0.51$ & $33.0 \pm 14.17$ & 131.2 \\
\hline OT136 & $102.2 \pm 5.38$ & $3.0 \pm 1.0$ & $49.0 \pm 4.58$ & 125.3 \\
\hline OT139 & $103.8 \pm 5.62$ & $2.3 \pm 1.12$ & $57.0 \pm 3.0$ & 127.3 \\
\hline OT140 & $99.6 \pm 6.69$ & $3.3 \pm 0.51$ & $62.0 \pm 9.16$ & 122.2 \\
\hline OT148 & $84.4 \pm 4.22$ & $2.0 \pm 1.0$ & $45.0 \pm 10.8$ & 103.5 \\
\hline OT151 & $80.0 \pm 3.36$ & $1.6 \pm 0.57$ & $28.0 \pm 2.48$ & 98.1 \\
\hline $\mathrm{OC} 107^{(2)}$ & $92.6 \pm 3.00$ & $2.3 \pm 0.57$ & $53.0 \pm 5.56$ & 113.6 \\
\hline OC109 & $79.5 \pm 6.47$ & $1.6 \pm 1.15$ & $43.0 \pm 6.24$ & 97.5 \\
\hline Control & $81.5 \pm 2.14$ & - & - & 100 \\
\hline OT102 $2^{(1)}$ & $104.0 \pm 3.98$ & $2.0 \pm 1.0$ & $46.0 \pm 11.0$ & 127.6 \\
\hline OT103 & $103.0 \pm 1.99$ & $2.3 \pm 1.5$ & $48.0 \pm 4.58$ & 126.3 \\
\hline OT111 & $98.8 \pm 2.27$ & $1.6 \pm 1.15$ & $51.0 \pm 10,58$ & 121.2 \\
\hline OT114 & $89.8 \pm 5.57$ & $2.6 \pm 0.52$ & $49.0 \pm 8.18$ & 110.1 \\
\hline OT115 & $74.8 \pm 2.41$ & $2.3 \pm 0.57$ & $35.0 \pm 4.58$ & 91.7 \\
\hline OT117 & $111.0 \pm 3.97$ & $2.6 \pm 1.96$ & $59.0 \pm 3.0$ & 136.1 \\
\hline OT118 & $88.0 \pm 1.52$ & $1.3 \pm 0.57$ & $48.0 \pm 7.0$ & 107.9 \\
\hline OT121 & $101.0 \pm 8.08$ & $10.0 \pm 2.64$ & $63.0 \pm 8.88$ & 123.9 \\
\hline OT122 & $87.0 \pm 6.38$ & $4.6 \pm 1.44$ & $58.0 \pm 11.53$ & 106.7 \\
\hline OT123 & $93.6 \pm 6.86$ & $2.3 \pm 0.57$ & $51.0 \pm .56$ & 114.8 \\
\hline OT124 & $97.5 \pm 6.26$ & $2.6 \pm 0.69$ & $53.0 \pm 6.0$ & 119.6 \\
\hline OT130 & $107.0 \pm 4.17$ & $2.3 \pm 0.51$ & $33.0 \pm 14.17$ & 131.2 \\
\hline OT136 & $102.2 \pm 5.38$ & $3.0 \pm 1.0$ & $49.0 \pm 4.58$ & 125.3 \\
\hline OT139 & $103.8 \pm 5.62$ & $2.3 \pm 1.12$ & $57.0 \pm 3.0$ & 127.3 \\
\hline OT140 & $99.6 \pm 6.69$ & $3.3 \pm 0.51$ & $62.0 \pm 9.16$ & 122.2 \\
\hline OT148 & $84.4 \pm 4.22$ & $2.0 \pm 1.0$ & $45.0 \pm 10.8$ & 103.5 \\
\hline OT151 & $80.0 \pm 3.36$ & $1.6 \pm 0.57$ & $28.0 \pm 2.48$ & 98.1 \\
\hline $\mathrm{OC} 107^{(2)}$ & $92.6 \pm 3.00$ & $2.3 \pm 0.57$ & $53.0 \pm 5.56$ & 113.6 \\
\hline OC109 & $79.5 \pm 6.47$ & $1.6 \pm 1.15$ & $43.0 \pm 6.24$ & 97.5 \\
\hline
\end{tabular}

Note: Values are the \pm SE, $\mathrm{n}=3$; ARA - acetylene-reductase activity. $\mathrm{OT}^{(1)}$ - nodule bacteria isolated from Onobrychis transcaucasica nodules; $\mathrm{OC}^{(2)}$ - nodule bacteria isolated from Onobrychis chorassanica nodules.

Thus, proceeding from these results one can suppose that more optimal growing conditions which are close to natural conditions of their habitats are necessary for nodulation of Onobrychis transcaucasica and Onobrychis chorasanica plants, because these plants are wild plants.

\subsection{Phylogenetic Analysis of the $16 \mathrm{~S}$ rRNA Gene of Nodule Bacteria Strains}

Further, the taxonomy of bacterial isolates of nodule bacteria isolated from nodules of Onobrychis transcaucasica and Onobrychis chorassanica plants was studied with help of 16S rRNA gene method. The determination of nucleotide sequence of $16 \mathrm{~S}$ rRNA gene of nodule bacteria of Onobrychis plants enabled to realize an identification of specific belonging of the bacteria up to genus, but for some bacteria - up to specie. Results of comparative BLAST analysis of nucleotide sequence of conservative region of $16 \mathrm{~S}$ rRNA gene of OT102, OT123, OT136, OT140 bacteria from Onobrychis transcaucasica were identical with genes of Rhizobium sp. EGY2 (AY693662.1) by 99\%. It is interesting to note that nucleotide sequences of OT102, OT103, OT111, OT115, OT117, OT123, OT136, OT139, OT140 bacteria from Onobrychis transcaucasica have also $96-98 \%$ identity with genes of Sinorhizobium meliloti CCNWYC140 (EU849576.1), Sinorhizobium meliloti (AB535707.1), 
Table 2. Nodulation of Onobrychis chorassanica plants under inoculation with nodule bacteria strains isolated from Onobrychis plants.

\begin{tabular}{ccccc}
\hline Inoculation variant & $\begin{array}{c}\text { Average dry biomass of } \\
\text { 1 plant, } \mathrm{mg}\end{array}$ & $\begin{array}{c}\text { Average nodule } \\
\text { number per 1 plant }\end{array}$ & $\begin{array}{c}\text { ARA, nmoles } \\
\mathrm{C}_{2} \mathrm{H}_{4} / \text { tube/hour }\end{array}$ & $\begin{array}{c}\text { Efficiency } \\
\text { symbiosis, \% }\end{array}$ \\
\hline Control & $75.3 \pm 3.30$ & - & - & 100 \\
OC104 & $101.4 \pm 8.48$ & $2.6 \pm 0.57$ & $42.0 \pm 4.58$ & 134 \\
OC106 & $94.8 \pm 5.18$ & $1.6 \pm 0.57$ & $47.0 \pm 6.08$ & 125 \\
OC107 & $95.6 \pm 2.85$ & $1.6 \pm 1.15$ & $43.0 \pm 7.0$ & 126.9 \\
OC109 & $97.1 \pm 7.01$ & $2.3 \pm 1.15$ & $45.0 \pm 3.0$ & 128.9 \\
OC111 & $80.0 \pm 9.64$ & $1.3 \pm 0.51$ & $39.0 \pm 3.46$ & 106.2 \\
OC112 & $90.8 \pm 3.63$ & $2.6 \pm 1.09$ & $41.0 \pm 6.0$ & 120.5 \\
OC113 & $81.4 \pm 6.50$ & $1.3 \pm 0.57$ & $37.0 \pm 6.24$ & 108.1 \\
OC138 & $78.6 \pm 2.89$ & $1.7 \pm 0.64$ & $40.0 \pm 3.6$ & 104.3 \\
OT102 & $77.2 \pm 4.38$ & $2.3 \pm 1.12$ & $43.0 \pm 8.88$ & 102.6 \\
OT103 & $96.8 \pm 2.11$ & $3.3 \pm 1.15$ & $48.0 \pm 3.6$ & 128.5 \\
OT111 & $92.4 \pm 5.93$ & $1.6 \pm 0.57$ & $29.0 \pm 9.84$ & 122.7 \\
OT115 & $72.0 \pm 6.38$ & $1.3 \pm 0.6$ & $38.0 \pm 2.64$ & 95.6 \\
OT117 & $91.8 \pm 4.83$ & $1.6 \pm 0.69$ & $39.0 \pm 6.92$ & 121.9 \\
OT121 & $75.6 \pm 6.61$ & $1.3 \pm 1.15$ & $46.0 \pm 2.64$ & 100.3 \\
OT123 & $99.0 \pm 5.76$ & $2.3 \pm 1.15$ & $31.0 \pm 6.0$ & 131.4 \\
OT136 & $97.5 \pm 5.80$ & $2.6 \pm 1.52$ & 129.4 \\
\hline
\end{tabular}

Sinorhizobium fredii CCBAU 10078 (GU552900.1), Mesorhizobium mediterraneum Zw-2-1 (GU201845.1), Mesorhizobium obiense Zw-1 (GU201844.1), Bradyrhizobium japonicum PRY65 (AF239848.2) bacteria. The conservative region of 16S rRNA gene of OT114, OT124, OT148 bacteria coincides by $98-99 \%$ with genes of Pantoea agglomerans GS2 (GQ374474.1), Enterobacter cloacae IHB B 1374 (GU186117.1) and Pantoea agglomerans MKPTK-4 bacteria (GQ499274.1) accordingly.

Analogous results were obtained for nodule bacteria from Onobrychis chorassanica. The analysis of $16 \mathrm{~S}$ rRNA gene of Onobrychis chorassanica nodule bacteria showed that nucleotide sequence of OC104, OC107, OC109 and OC111 bacteria by 98- 99\% coincides with genes of Rhizobium sp. EGY2 (AY693662.1). Moreover, 16S rRNA genes of OC104, OC107, OC109 bacteria by $97-99 \%$ were homologous with genes of several bacteria species such as Sinorhizbium meliloti CCNWY C140 (EU849576.1), Sinorhizobium meliloti YcS2 (AB535707.1), Sinorhizobium fredii CCBAU 10078 (GU 552900.1), Mesorhizobium tianshanense (FM203306.1), Mesorhizobium amorphae CCNWYC131 (EU849577.1) and Bradyrhizobium japonicum PRY62 bacteria (AF 239847.2). OC112 bacterium is identical by $99 \%$ with nucleotide sequences of 16S rRNA gene of Burkholderia caryophylli WAB1944 (AM184283.1), the genes of OC106 coincides by $97 \%$ with genes of Pantoea agglomerans HXJ (HM016799.1), genes of OC138 by $98 \%$ coincides with genes of Enterobacter sp. RF-100 (GQ 205104.1) and genes of OC113 bacteria by $97 \%$ are identical with genes of Enterobacter sp. B-13M3 (AJ 874743.1).

During analysis of phylogenetic tree of created on the basis of nucleotide sequence of $16 \mathrm{~S}$ rRNA gene of different bacteria it was established that studied OT102, OT103, OT111, OT115, OT117, OT123, OT136, OT139, OT140 bacteria from Onobrychis transcaucasica were related to Alphaproteobacteria class (Figure 4(a)), but OT114, OT124, OT148 bacteria were related to Gammaproteobacteria class (Figure 4(b)). On phylogenetic tree of Onobrychis chorassanica nodule bacteria unlike to Onobrychis transcaucasica bacteria formed three clusters. Bacteria, incoming into the $1^{\text {st }}$ cluster, were Alphaproteobacteria (Figure 5(a)), the $2^{\text {nd }}$ cluster-Betaproteobacteria (Figure 5(b)), and bacteria of the $3^{\text {rd }}$ cluster were related to Gammaproteobacteria class, in particular to Enterobacter and Panoea genera (Figure 5(c)).

\subsection{Immobilization of Sand with Onobrychis Plants}

The seeds of both Onobrychis transcaucasica and Onobrychis chorassanica plants were sowed into sabulous sand of experimental desert trial plot; there was an average $17 \%$ of sand humidity at the plot under 3 additional irrigation treatments within 5-6 months. The sprouts emerged already by $2^{\text {nd }}-3^{\text {rd }}$ day after seed sowing and they developed up to stage with real (non-embryonal) leaves already by $6-8^{\text {th }}$ day. During the further 5-6 months the plants grew and gave a good yield of green biomass ( 2 hay cuttings were for the mentioned period) and within this time they formed compact "green belt" of 


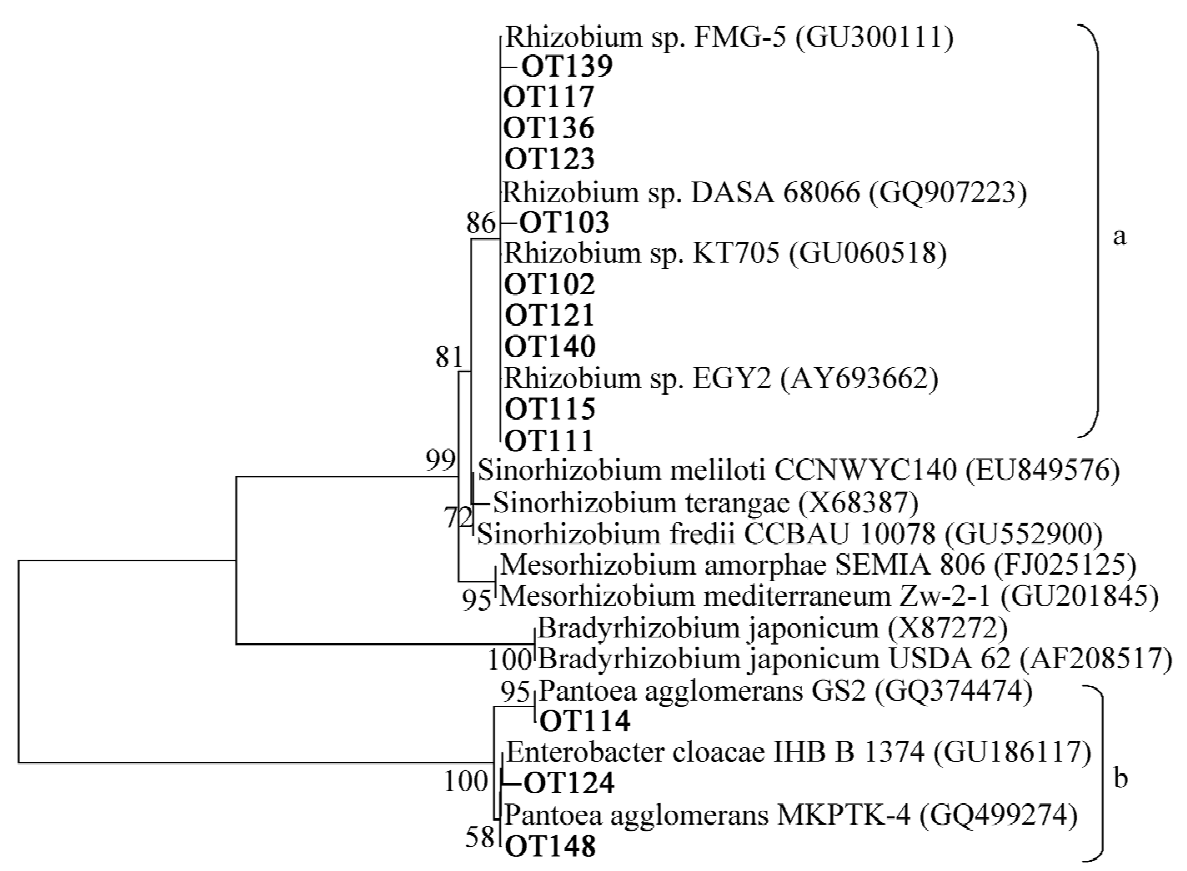

$\longdiv { 0 . 0 2 }$

Figure 4. Phylogenetic tree based on the 16S rRNA gene strains of nodule bacteria Onobrychis transcaucasica: (a) Alphaproteobacteria; (b) Gammproteobacteria. The branching pattern was produced by the neighbour-joining method. The GenBank accession numbers for the sequences used are indicated in parentheses. Symbionts of Onobrychis transcaucasica are shown in bold type.

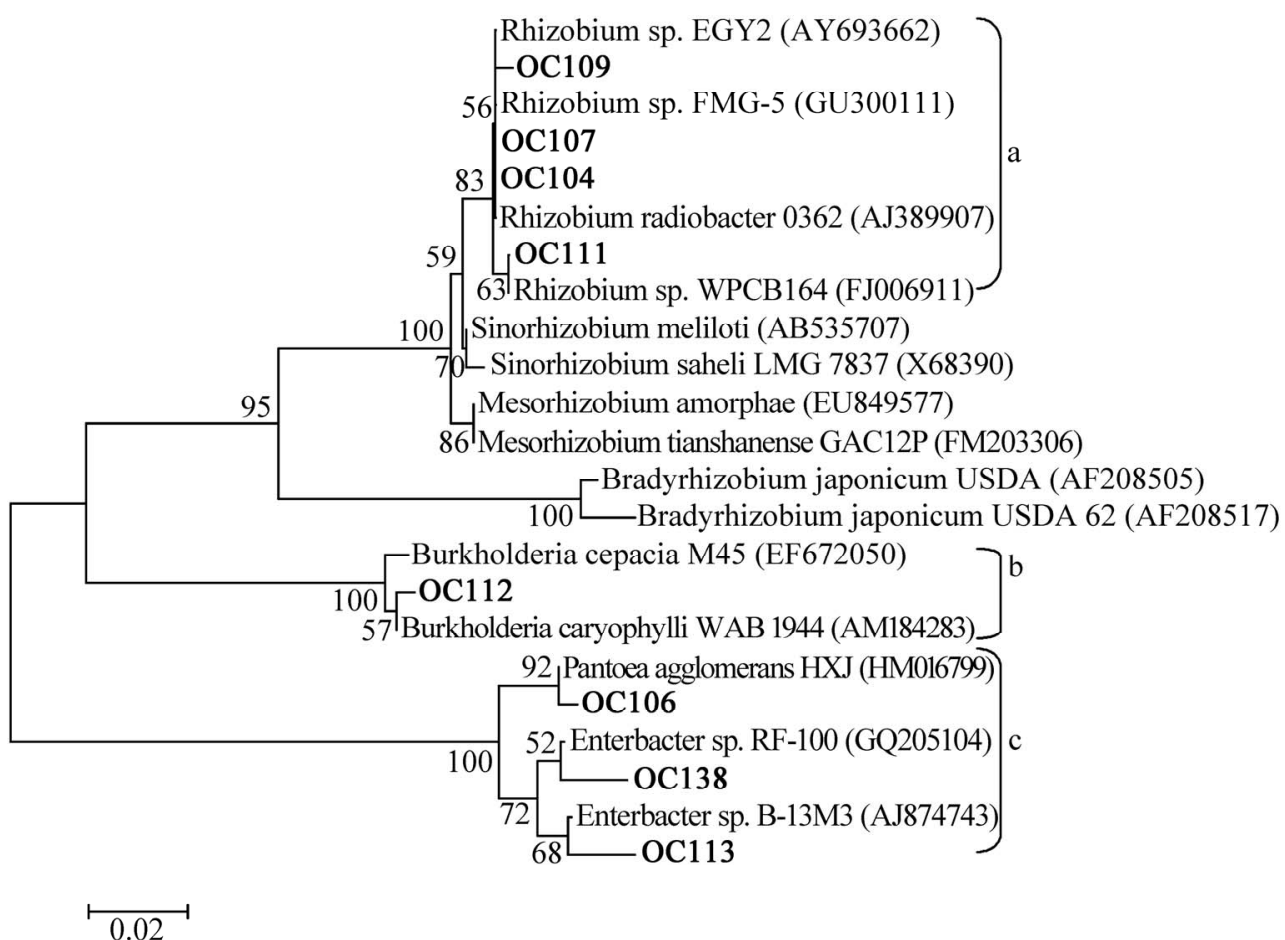

Figure 5. Phylogenetic tree based on the 16S rRNA gene strains of nodule bacteria Onobrychis chorassanica: (a) Alphaproteobacteria; (b) Betaproteobacteria; c- Gammproteobacteria. The branching pattern was produced by the neighbour-joining method. The GenBank accession numbers for the sequences used are indicated in parentheses. Symbionts of Onobrychis chorassanica are shown in bold type. 
75-100 $\mathrm{cm}$ (Figure 1), the plants blossomed and produced seeds thereby providing a renewal of the "green belt". The dry biomass of Onobrychis transcaucasica plants reached $323-428 \mathrm{~g} / \mathrm{m}^{2}$, while biomass of Onobrychis chorassanica plants was $390-714 \mathrm{~g} / \mathrm{m}^{2}$ in dependence on inoculation with different nodule bacteria strains (Table 3). Considerable increase of Onobrychis transcaucasica biomass was observed at inoculation of plants with OT121, OT123, OT136 strains. Under crossand direct inoculation of Onobrychis chorassanica plants with OC107, OT118, OT121 strains the highest biomass of plants in comparison with control plants biomass was recorded. It should be noted that under inoculation of plants the numerous nodules on plant roots of both Onobrychis transcaucasica (nodule number on each plant exceeded 500 units per 1 plant) and Onobrychis chorassanica (more 200 nodules / plant) were detected (Table 3, Figure 6). During development of root system the plants immobilized significant amount of sand, where Onobrychis transcaucasica plants had a fibrous (racemose) root system (Figure 6). The measurements of sand accumulation near the foot of the plants showed that if on the edges of the experimental plot there was a layer of sand with $5 \mathrm{~cm}$ height, then within internal zone of the plot (in furrows, between rows) the sand layer of 2-3 cm height was detected. By the $2^{\text {nd }}$ year of plants vegetation the sustainable growth of Onobrychis plants was recorded (Figure 7), where together with adult (mature) plants it was possible to observe an appearance of plenty young sprouts of fallen seeds (seedfall).

Table 3. Sand immobilization with Onobrychis plants (field experiments during 5 months at the Kyzil-Kum Desert Biostastion).

\begin{tabular}{|c|c|c|c|c|}
\hline \multirow{2}{*}{$\begin{array}{l}\text { Inoculation } \\
\text { variant }\end{array}$} & \multicolumn{2}{|c|}{ Onobrychis transcaucasica } & \multicolumn{2}{|c|}{ Onobrychis chorassanica } \\
\hline & $\begin{array}{l}\text { Average dry shoot } \\
\text { plant biomass, } \mathrm{g} / \mathrm{m}^{2}\end{array}$ & $\begin{array}{l}\text { Average height of sand } \\
\text { layer at foot of plants, cm }\end{array}$ & $\begin{array}{l}\text { Average dry shoot } \\
\text { plant biomass, } \mathrm{g} / \mathrm{m}^{2}\end{array}$ & $\begin{array}{l}\text { Average height of sand } \\
\text { layer at foot of plants, } \mathrm{cm}\end{array}$ \\
\hline Control & $329 \pm 22.0$ & & $350 \pm 39.0$ & \\
\hline OT102 & $347 \pm 34.0$ & & $552 \pm 30.99$ & \\
\hline OT103 & $361 \pm 22.0$ & & $409 \pm 8.0$ & \\
\hline OT115 & $323 \pm 19.0$ & & $504 \pm 51.0$ & \\
\hline OT117 & $342 \pm 24.0$ & & $457 \pm 20.41$ & \\
\hline OT118 & $400 \pm 20.99$ & & $695 \pm 22.99$ & \\
\hline OT121 & $423 \pm 40.0$ & $2-3$ & $698 \pm 33.0$ & $2-3$ \\
\hline OT123 & $428 \pm 27.0$ & & $390 \pm 25.0$ & \\
\hline OT136 & $428 \pm 28.9$ & & $433 \pm 11.99$ & \\
\hline OC104 & $419 \pm 2.0$ & & $480 \pm 13.0$ & \\
\hline OC107 & $380 \pm 34.99$ & & $714 \pm 14.99$ & \\
\hline OC109 & $390 \pm 25.99$ & & $438 \pm 36.0$ & \\
\hline OC111 & $340 \pm 25.0$ & & $498 \pm 20.99$ & \\
\hline
\end{tabular}

Note: Values are the means \pm SE, $n=2$; nodule number on each plant exceeded 500 units per 1 plant Onobrychis transcaucasica (Onobrychis chorassanica - more 200 nodules / plant), their size varied within range for Onobrychis transcaucasica 0.3 - $1.7 \mathrm{~cm}$ in diameter $(0.3-2.2 \mathrm{~cm}$ for Onobrychis chorassanica plants). Height of Onobrychis plants varied within range $75-100 \mathrm{~cm}$ and length of roots $-45-65 \mathrm{~cm}$.

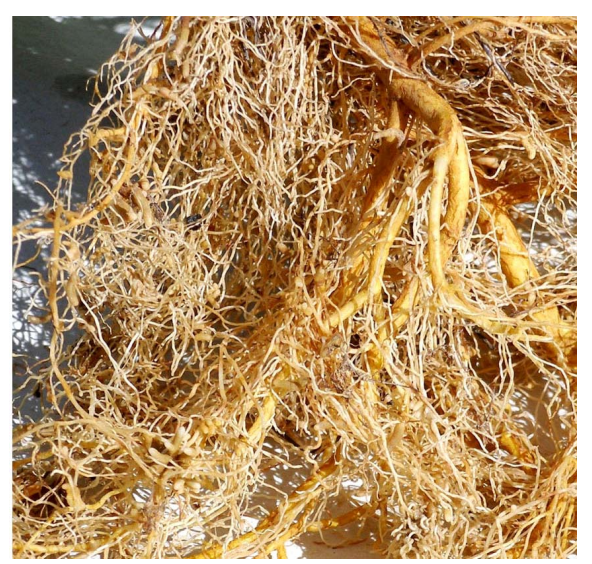

(a)

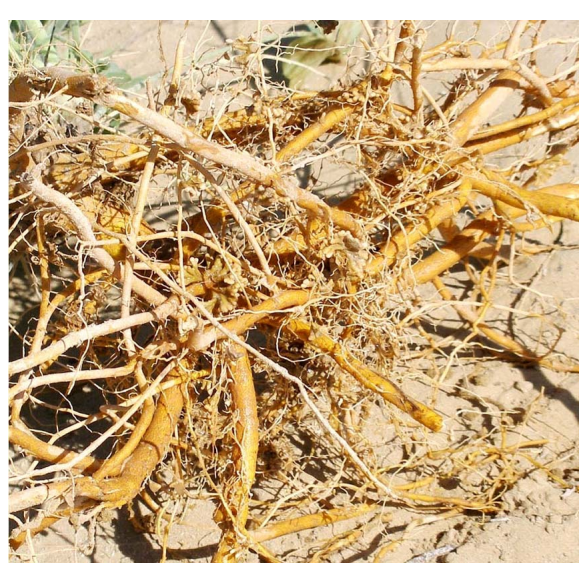

(b)

Figure 6. The root system of Onobrychis transcaucasica (a) and Onobrychis chorasanica (b). 


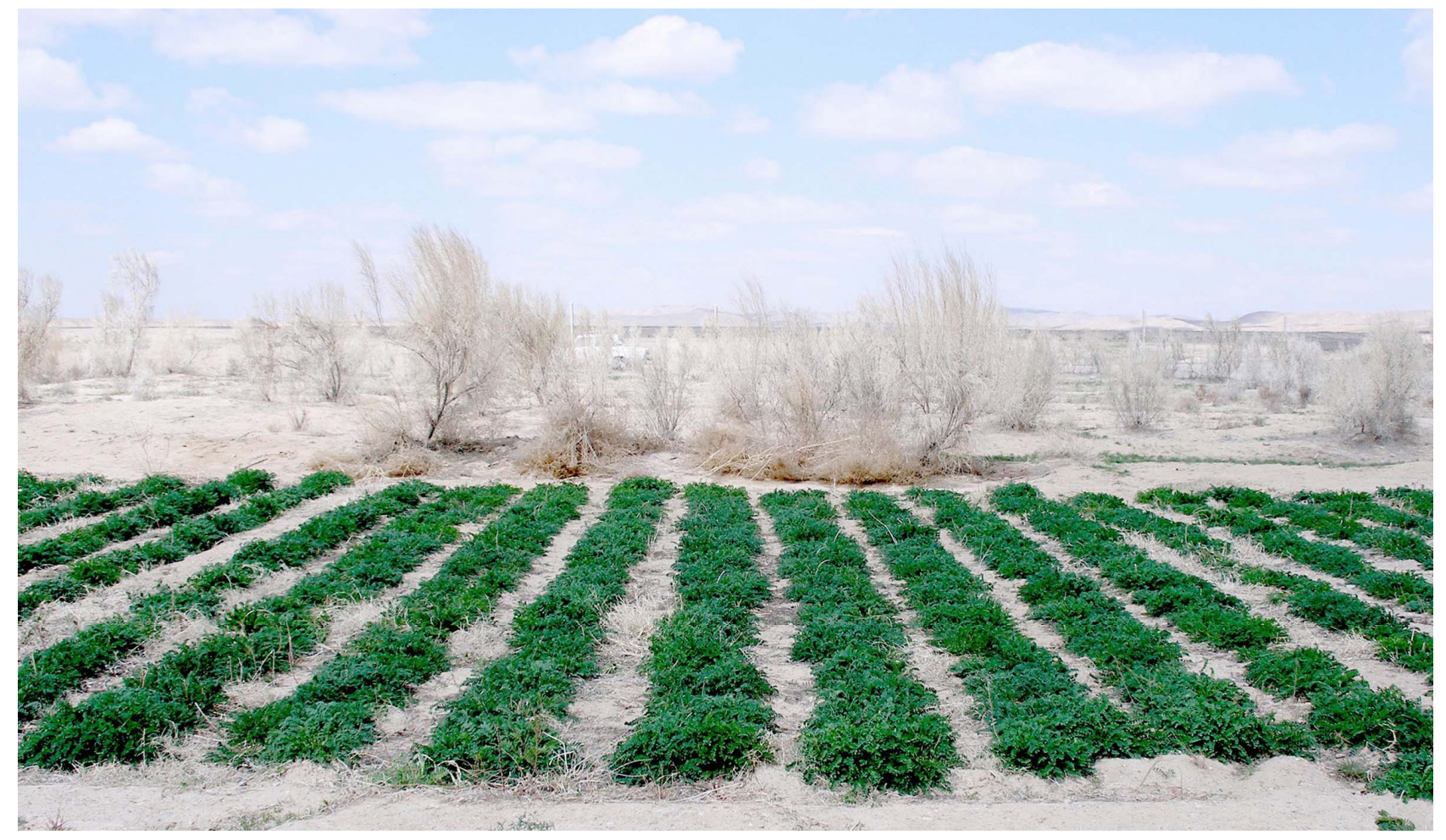

Figure 7. The 2nd year, early spring, of vegetation of Onobrychis transcaucasica plants at experimental trial plot (model pasture) at Kyzyl-Kum Desert Biostation (Scientific Center of Plant Production "Botanika", Uzbekistan Academy of Sciences).

Thus, with help of Onobrychis plants it is possible to conduct an efficient sand immobilization in a way of their growing on blown sand on condition of necessary irrigation and create artificial pastures in semi-desert conditions in order to increase a productivity of natural pastures. But for this it is necessary to support moisture of sabulous soil (sandy clay) no less than $17 \%$ for active vegetation (maximal average moisture of desert sand observed in spring season), blossoming and obtaining of real crop yield of Onobrychis plants in conditions of deserted soils.

\section{Discussion}

Some works devoted to nodulation of leguminous plants with bacteria related to Bettaproteobacteia and Gammaproteobacteria classes are published lately [19-22]. First L. Moulin with other authors established that bacteria of Burkholderia genus [20] formed normal nodules on plant roots. Then other researchers found that isolates of root nodule bacteria from two Mimosa species at three sites in Costa Rica belonged to the genera Burkholderia, Cupriavidus, and Rhizobium. Inoculation tests further indicated that both Cupriavidus and Burkholderia spp. resulted in significantly higher plant growth and nodule nitrogenase activity relative to plant performance with strains of Rhizobium [21]. Under identification of bacteria isolated from nodules of Prosopis juliflora it was shown that in addition to traditional nodule bacteria the bacteria which had $100 \%$ of homology with Achromobakter xylosoxidans were found [22]. The repeated inoculation of Prosopis juliflora plants with these bacteria led to formation of nitrogen-fixing nodules on plant roots. In the bacteria it was determined an availability of nodC gene that is responsible for nodule formation in legume plants. In other works from the root nodules of the three Mediterranean wild legume species Hedysarum carnosum, Hedysarum spinosissimum subsp. capitatum and Hedysarum pallidum there were isolated bacteria which belonged to the class Gammaproteobacteria and included Pantoea agglomerans, Enterobacter kobei, Enterobacter cloacae, Leclercia adecarboxylata, Escherichia vulneris, and Pseudomonas sp [23].

In our research devoted to Onobrychis plant nodulation we also had heterogeneity of bacteria isolated from nodules. Determination of generic and specific composition of bacterial isolates from nodules of Onobrychis transcaucasica and Onobrychis chorassanica plants showed that 16S rRNA genes of bacteria were highly identical as to Alphaproteobacteria, well as to Betta- and Gammaproteobacteria. The studied OT102, OT103, 
OT111, OT115, OT117, OT121, OT123, OT136, OT139, OT140 bacteria from Onobrychis transcaucasica were related to Rhizobium genus (Alphaproteobacteria / Rhizobiales / Rhizobiaceae / Rhizobium), while OT114, OT148 bacteria were related to Patnoea genus and OT124 strain-to Enterobacter genus (Gammaproteobacteria / Enterobacteriales / Enterobacteriaceae / Enterobacter, Pantoea). Bacteria from Onobrychis chorassanica unlike to bacteria from Onobrychis transcaucasica on their 16S rRNA genes were related to three classes of bacteria-Alphaproteobacteria, Betaproteobacteria, Gammaproteobacteria. OC104, OC107, OC109, OC111 bacteria were related to Rhizobium genus, OC112 bacterium - to Burkholderia genus (Betaproteobacteria, Burkholderiales, Burkholderiaceae, Burkholderia) and OC106, OC118 and OC138 bacteria were related to Enterobacter genus. If to consider the origin of nodule bacteria from both Onobrychis plant species, then it is possible to notice that the most of studied bacteria are very close neighbours incoming into the same genus of bacteria. But as a whole the nodule bacteria from Onobrychis plants comprise a wide scope on phylogenetic tree.

Under studying of nodulation of Onobrychis plants it has been established that in microvegetation experiment the shoot part of plants was by 2 times longer than root part and very low nodulation was observed. In vegetation experiment the plant roots developed well and the root length was by 3 times longer than the length of shoot part of plants and practically in all variants the nodules were formed. Proceeding from these results one can suppose that intense growth and root development are one of the main criteria that determines the nodulation in both Onobrychis transcaucasica and Onobrychis chorassanica plants. The nodule bacteria independently on their belonging to one or another bacterial genus formed full nitrogen-fixing nodules on Onobrychis plants. It should be noted that OT103, OT111 and OT117 strains displayed a high efficiency in both Onobrychis transcaucasica host plant and Onobrychis chorasanica plant too. As our field experiments showed, growing up of inoculated Onobrychis transcaucasica and Onobrychis chorsasanica plants in sabulous sandy soils in the Kyzil-Kum Desert showed a possibility of sand immobilization with its further stabilization. In addition to stabilization of blown sand it is possible to increase a productivity of semi-deserted by means of creation of artificial renewable pastures - if in natural conditions the productivity of desert pasture comprises usually 100-300 kg/ha (24), then on condition of minimal additional irrigation of Onobrychis transcaucasica and Onobrychis chorassanica symbiosis in sabulous soils it is possible to increase this productivity up to $30-70 \mathrm{c} / \mathrm{ha}$.

Thus, Onobrychis nitrogen-fixing symbiosis can be used for both increase of biological fertility (restoration) of poorer deserted soils which would promote the desert flora diversity and immobilization of sandy soils with aim to increase of productivity of deserted and semideserted pastures under minimal irrigation measures.

\section{Acknowledgements}

Authors express a deep gratitude to Dr. M. Ines M. Soares and Prof. Herman Lips (Institute for Desert Research Ben-Gurion University of the Negev Sede Boqer, Israel), Dr. Jhonathan E. Ephrath (Wyler Dept. for Dryland Agriculture, Jacob Blaustein Institute for Desert Research, Ben-Gurion University of the Negev, Sede Boqer, Israel) for help and consultations in carrying out of microbiological, molecular-genetic and field experiments. These investigations were carried out owing to grant support of USAID/CDR/CAR Program.

\section{REFERENCES}

[1] M. D. Rumbaugh, "Special Purpose Forage Legumes," In: J. Janick and J. E. Simon, Ed., Advances in New Crops. Timber Press, Portland, OR, 1990, pp. 183-190.

[2] H. Blasum, "Wild legumes, vetch inoculation, and rhizobial taxonomy in Xiaman farm, eastern edge of the Qinghai-Tibet plateau", MS Thesis. http://www.blasum.net/ holger/wri/alpleg/index.html

[3] D. Prévost, P. Drouin, S. Laberge, A. Bertrand, J. Cloutier and G. Lévesque, "Cold-Adapted Rhizobia for Nitrogen Fixation in Temperate Regions," Canadian Journal of Botany, Vol. 81, 2003, pp. 1153-1161.

[4] G. Laguerre, P. Van Berkum, N. Amarger and D. Prevost, "Genetic Diversity of Rhizobial Sym-bionts Isolated from Legume Species within the Genera Astragalus, Oxytropis and Onobrychis," Applied Environmental Microbiology, Vol. 63, December 1997, pp. 4748-4758.

[5] D. Prevost, L. M. Bordeleau and H. Antoun, "Symbiotic Effectiveness of Indigenous Arctic Rhizobia on a Temperate Forage Legume: Sainfoin (Onobrychis viciifolia)," Plant and Soil, Vol. 104, No. 1, March 1987, pp. 63-69.

[6] D. Prévost, H. Antoun and L. M. Bordeleau, "Effects of Low Temperature on Nitrogenase Activity in Sainfoin (Onobrychis viciifolia) Nodulated by Arctic Rhizobia," FEMS Microbiology Ecology, Vol. 45, 1987, pp. 205210.

[7] R. J. Roughley, "The Influence of Root Temperature, Rhizobium Strain and Host Selection on the Structure and Nitrogen-Fixing Efficiency of the Root Nodules of Trifolium subterraneum," Annals of Botany, Vol. 34, 1970, pp. 631-664.

[8] P. H. Graham, "Co-evolution of Phaseolus Vulgaris and Its Rhizobia," University of Minnesota, Department of Soil, Water, and Climate, College of Agricultural, Food, and Environmental Sciences, Rhizobia Research Laboratory.

[9] Z. Zhao, S. E. Williams and G. E. Schuman, "Renodula- 
tion and Characterization of Rhizobium Isolates from Cicer Milkvetch (Astragalus cicer L.)," Biology and Fertility of Soils, Vol. 25, No. 2, August 1997, pp. 169-174.

[10] A. U. Khotyanovich, "Methods for Cultivation of Nitrogen-Fixing Bacteria, Ways of Both Their Obtaining And Preparing of Preparations on Their Base (Methodical Guides)," All-Union Institute of Agricultural Microbiology, Leningrad, 1991, pp. 33-60.

[11] D. R. Hoagland, D. J. Arnon, "The Water Culture Method for Growing Plants without Soil," California Agricultural Experimental Station, Vol. 347, 1938, pp. 1-32.

[12] D. W. Hardy, R. Halstein, E. Jakson and R. S. Buens, " $\mathrm{C}_{2} \mathrm{H}_{2}-\mathrm{C}_{2} \mathrm{H}_{4}$ Assay to $\mathrm{N}_{2}$ Fixation Laboratory and Field Evaluation," Plant Physiology, Vol. 43, 1968, pp. 9-13.

[13] M. J. Ferris, G. Muyzer and D. M. Ward, "Denaturing Gradient Gel Electrophoresis Profiles of 16S rRNA-Defined Populations Inhabiting a Hot Spring Microbial Mat Community," Applied Environmental Microbiology, Vol. 62, February 1996, pp. 340-346.

[14] S. F. Altschul, T. L. Madden, A. A. Schaffer, J. Zhang, Z. Zhang, W. Miller and D. J. Lipman "Gapped: BLAST and PSI-BLAST: A New Generation of Protein Database Search Programs," Nucleic Acids Research, Vol. 25, September 1997, pp. 3389-3402.

[15] N. Saitou and M. Nei, "The Neighbour-Joining Method: a New Method for Reconstructing Phylogenetic Trees," Molecular Biology Evolution, Vol. 4, July 1987, pp. 406-425.

[16] K. Tamura, J. Dudley, M. Nei, S. Kumar, "MEGA4: Molecular Evolutionary Genetics Analysis (MEGA) software version 4.0", Molecular Biology and Evolution, Vol. 24, 2007, pp. 1596-1599.

[17] O. Kh. Khasanov, S. F. Tadjiev, L. Shamsuvalieva, V. I.
Konycheva and T. Rakhimova, "Onobrychis Chorasanica Bge. - esparcette chorasanskii," In: D. K. Saidov, Ed., Adaptation of Forage Plants to Conditions of Arid Zone of Uzbekistan, "Fan" of Uzbek SSR, Tashkent, 1983, pp. 236-245.

[18] A. G. Borisova, "New Species of Onobrychis for Cultivation," USSR Academy of Sciences Press, 1952.

[19] H. Zahran, "Rhizobia from Wild Legumes: Diversity, Taxonomy, Ecology, Nitrogen Fixation and Biotechnology," Journal of Biotechnology, Vol. 91, No. 2-3, October 2001, pp. 143-153.

[20] L. Moulin, A. Munive, B. Dreyfus and C. Boivin-Masson, "Nodulation of legumes by members of the beta-subclass of Proteobacteria", Nature, Vol. 411, June 2001 pp. 948-950.

[21] C.F. Barrett, M. A. Parker, "Coexistence of Burkholderia, Cupriavidus, and Rhizobium sp. Nodule Bacteria on Two Mimosa spp. in Costa Rica," Applied and Environmental Microbiology, Vol. 72, No. 2, February 2006, p. 1198-1206.

[22] B. Hanane, M. Ourarhi, N. Boukhatem, A. Berrichi, A. Hanaa, M. Rosella, S. Andrea and M. M. El Idrissi, "Diver- sity of Bacteria that Nodulate Prosopis juliflora in the Eastern Area of Morocco," Systematic and applied micro- biology, 2008, Vol. 31, No. 5, pp. 378-386.

[23] Y. Benhizia, H. Benhizia, A. Benguedouar, R. Muresu, A. Giacomini and A. Squartini, "Gamma Proteobacteria Can Nodulate Legumes of the Genus Hedysarum", Systematic and Applied Microbiology, Vol. 27, No. 4, 2004, pp. 462-468.

[24] D. K. Saidov, "Ecological-Biological Fundamentals for Creation of Artificial Pastures and Haymakings on Adyrs of the Ferghana Valley," Tashkent, “Fan”, 1977. 